stater forandrer figurationerne indadtil. Staten bliver centreret omkring en regent, og de tidligere krigerherskere underkastede sig eller blev henrettet af den nye enevældige hersker. Omkring kongen opstod hoffet, og hoffet var en figuration, hvor det private rum var fortrængt, og spontaniteten var blevet fortrængt langt ind under overjegets domæne. I hofsamfundet krævede det en konstant selvdisciplinering af mennesket at bevæge sig $i$ en figuration, hvor det ikke længere var ens drifter, der var den centrale drivkraft $i$ handlingerne. På denne måde var hofsamfundet en forudsætning, hvilken det moderne samfund byggede videre på. Det individualiserede og moderne samfund bygger på komplekse figurationer, hvor selvdisciplineringen hersker. Naturligvis mener Elias ikke, at det er grundlæggende samme mekanismer, der hersker i det moderne samfund, men det interessante er Elias pointering af sammenhængen mellem, hvordan vi - moderne mennesker - agerer i dag, og hvorledes dette er forbundet med den måde, hvorpå adelen agerede på i hoffet - i forholdet til kongen, borgerskabet og til andre medlemmer af hoffet.

Robert van Kriekens Norbert Elias er en velskrevet og udmærket introduktion til Elias forfatterskab. Nu ventes der blot på at Hans Reitzels Forlag eller et andet forlag oversætter et af Elias' centrale værker. Elias er en historisk sociolog, som ikke kun er væsentlig for sociologien, men både idehistorien, historien, psykologien og samfundsvidenskaber generelt.

Laust Keblet

\section{Erlebe dein Leben}

Det gode liv. Mere end dig selv, Niels Jakob Harbo m.fl. (red), Forlaget Philosophia, 149,00 kr.

Hvad er det gode liv? Er det dét liv der kommer til udtryk i reklamen med den unge kvinde, der hamrer sit kreditkort i bordet og siger 'Den frihed tager jeg mig'? Vi lader spørgsmålet stå et øjeblik. Eksemplet med kvinden og kreditkortet illustrerer en udbredt forståelse af hvad det gode liv er i dag: det gode liv er dét liv, hvor det enkelte menneske oplever størst mulig frihed til at tilfredsstille dets behov. Det ligger samtidig i denne forståelse, at det gode liv er dét liv der rummer et meget stort antal lystfyldte oplevelser. Skonne kunne denne type oplevelser også kaldes. I kraft af denne orientering efter skønne oplevelser, er det samfund vi lever i blevet karakteriseret som et oplevelsessamfund.

Hvordan står det til med lykken i et samfund der på denne måde sætter individet og dets behov for skønne oplevelser først? Dette spørgsmål tages under grundig og kritisk behandling af forfatterne bag den glimrende antologi Det gode liv - mere end dig selv.

Den svenske filosof Carl-Göran Heidegren henleder $i$ et af antologiens mest velskrevne bidrag op- 
mærksomheden på et paradoks ved oplevelsessamfundet: det går mange mennesker materielt godt i dag. De besidder derfor - objektivt set - en privilegeret position $\mathrm{i}$ henseende til at kunne virkeliggøre det gode liv. Alligevel er en stor del af disse mennesker ikke i stand til at udnytte denne position og virkeliggøre dette liv af den grund, at de simpelthen er ulykkelige. Hvad er grunden? En nærliggende og plausibel forklaring på dette paradoks er - ifølge Heidegren - at disse mennesker er ulykkelige, fordi de ikke kan magte at leve op til oplevelsessamfundets ideal om det gode liv. Det oplevelsesorienterede menneske plages nemlig af usikkerhed $i$ forhold til hvilke oplevelser det er værd at efterstræbe; hvilke der giver mest positivt udbytte; og af skuffelsen der opstår når oplevelsen viser sig ikke at svare til forventningerne. Oplevelsesorienteringen fjerner den enkelte fra det gode liv, og det gør den, fordi den fremelsker en individualisme i omgangen med andre.

Efter min opfattelse er Det gode liv - mere end dig selv ikke alene en vellykket, men i høj grad også en tiltrængt bog. Vellykket fordi bogens bidrag fremstiller det gode livs problematik på en måde så der rummes plads til både den videnskabelige dybde og det enkelt anskuelige. Antologien demonstrerer således ganske fint, at det gode liv er et anliggende der på samme tid vedrører den enkelte og det der rækker ud over den enkelte: På den ene side har mennesket brug for ind imellem at befinde sig i tilværelsens æstetiske, legende og lystfyldte dimension. På den anden side er det helt afgørende at det individuelle liv - hvis det skal lykkes som et godt liv - på samme tid har brug for at overskride denne dimension i retning af det fælles og kollektive.

Det gode liv er i dets traditionelle form knyttet til kollektivt forpligtende etiske og politiske fortællinger. Den rendyrkede oplevelsesorientering og den individualisme der opretholder denne orientering undergraver disse fortællinger. Kvinden der hamrer sit kreditkort i bordet - fordi hun fortjener det - fortjener at få konkurrence fra alternative ideer om gode liv, ideer der kan generobre og udvikle disse fortællinger. Som anledning til at tage fat på en diskussion af hvordan det kan ske, er Det gode liv - mere end dig selv derfor også en tiltrængt bog.

Ulrik Bisgaard

\section{Tiltrcengte genudgivelser}

Lars-Henrik Schmidt \& Jens Erik Kristensen: Lys, luft og renlighed - Den moderne socialhygiejnes fodsel, Akademisk Forlag, 2004 (opr. 1986), 261 s., 299 kr. og Michel Foucault: Sindssygdom og psykologi, Hans Reitzels Forlag, 2005 (opr. 1971 på dansk), 142 s., 175 kr.

I et smalt fagbogsområde som det danske løber ethvert forlag, der satser på at udgive filosofisk-idéhistorisk litteratur to former for risiko. På 